\title{
Economic Value Added Method as A Tools to Measure Financial Performance Assessment in PT. Campina Ice Cream Tbk.
}

\author{
Himza Fadhilah Putri Wulandari
}

Department of Management, Faculty of Economics and Business, Narotama University, Indonesia

\begin{abstract}
Every company established has a goal to gain profits and maximize wealth to shareholders. The purpose of this study is to analyze method of Economic Value Added as a measure of financial performance assessment at PT. Campina Ice Cream Industry Tbk. Method used in this study a Qualitative Descriptive approach. Data source in this study uses secondary data form of financial statements PT. Campina Ice Cream Industry Tbk in 2016-2018. Analysis data technique used is method of Economic Value Added. Economic Value Added shows the measurement of extent to which company has value added to owners of company in a given year or period. The results of this study can be concluded that Economic Value Added (EVA) at PT.Campina Ice Cream Industry Tbk in 2016 worth Rp. (3.656.510.875) and in 2017 valued at Rp. (2.473.733.162) so that it produces a negative Economic Value Added or> 0 which can be said that the company financial performance is not good. However, in 2018 company achieved scores. Economic Value Added $<0$ or positive worth Rp. 15.881.445.739 then, it can be concluded that company financial performance is good and has resulted in value added expected by the shareholders.
\end{abstract}

Keywords: Economic Value Added; Financial Performance; Financial Statements.

\section{Introduction}

The development of today's industrial business world requires companies to have good financial performance to attract external parties in order to be able to invest their capital or maintain investor investment. Every company that is established has a goal to gain profits and maximize the wealth of its shareholders. In addition, the company has a goal to maintain the survival of the company well so that it can develop in accordance with the activities carried out for the future. One of the new companies listed their shares in 2017, namely PT Campina Ice Cream Industri Tbk. PT Campina is the only company that focuses only on producing ice cream. However, the competition level of the ice cream industry has high competitiveness, there are a large number of producers that produce similar products which impact on the income performance of PT Campina Ice Cream Industri. The table 1, the company's 2016-2018 profit/loss.

Table 1 Data Net Profit After Tax PT Campina Ice Cream Industry Tbk

\begin{tabular}{llll}
\hline & 2016 & 2017 & 2018 \\
\hline Net Profit After Tax & 52.726 .852 .009 & 43.421 .734 .614 & 61.947 .295 .689 \\
\hline
\end{tabular}

(Source: PT Campina Ice Cream Industry Financial Statements)

PT Campina Ice Cream Tbk in 2017 experienced a decline in net profit worth 43.42 billion compared to 2016 which reached 52.37 billion. This is because the company's operating expenses increased to Rp.480,330,082,018 and the decrease in financial income generated by the company was Rp.3,778,226,720 which can result in decrease in net

\footnotetext{
* Corresponding author.

E-mail address: xxxx@xxxxxx.edu (First Author)
} 
profit after corporate tax. But in 2018 the company again experienced a fairly rapid increase worth 61.94. The increase in net profit was due to the reduced financial burden after debt repayment and the promotion efforts of the marketing team that continued to be improved.

In this case, it is very important that company appraise and evaluate performance that has been achieved by company within the time set. Assessment that is often used in measuring company performance using financial ratio analysis. However, financial ratio analysis still has weaknesses, one of the disadvantages of financial ratios is difficulty in choosing the right ratio and can be used for the interests of stakeholders. Financial performance assessment using financial ratios is only profit oriented, but at this time the company is required not only to be profit oriented but also to be value-oriented. To overcome these weaknesses, the method of Economic Value Added (EVA) is used.

Economic Value Added was first introduced by George Bennet Stewart is one of the managing partners of a leading management consultant, namely the Stern Stewart \& Coo headquartered in New York. Economic Value Added shows a good measure of how much the company has added value to the owners of the company in a given year or period. Financial performance is measured by the method, the Economic Value Added proportion of capital costs is included as one component of calculating company performance as a consideration in showing the level of risk of the company and helping the manager to make better investment decisions. If the company focuses on Economic Value Added, the company is consistent in managing the company's finances to maximize shareholder wealth.

According to (Rudianto, n.d.) EVA assessment can be measured by provisions. If EVA is more than 0, the positive EVA value indicates that there has been a value added process in the company. If EVA is equal to 0 indicates the position does not experience setbacks and progress. If EVA is less than 0 which means negative EVA indicates no value added process occurs. In the quote (I.N.Adiguna., S.Murni., 2015).

\section{Literature Review}

\subsection{Financial Statements}

Financial statements are information that describes the financial condition of a company that can be used as an illustration of the company's financial performance. According to PSAK No. 1 (revised 2009) states that financial statements are a structured presentation of the financial position and financial performance of an entity. So financial statements are one of the most important information in assessing a company's development. From some opinions above it can be concluded that financial statements are the most important part of the company in order to provide information on the extent to which companies develop in managing the company's financial activities. The form of financial statements includes Balance Sheet reports, Profit and Loss reports, Equity reports.

\subsection{Financial Statement Analysis}

Financial statement analysis is a method that helps decision makers to know the strengths and weaknesses of the company through information obtained from financial statements. Financial statement analysis can help management to identify weaknesses or weaknesses that exist and then make rational decisions to improve company performance in order to achieve company goals. Financial report analysis is also useful for investors and creditors in making investment and credit decisions. According to Sofyan S Harahap (2007: 18) financial statement analysis is carried out with the following objectives:

1) Screening, analysis is carried out with the aim of knowing the situation and condition of the company from the financial statements without going directly to the field.

2) Understanding, carried out with the aim of understanding the company, the conditions financial, and the results of its business.

3) Forecasting, Analysis is used to forecast the company's financial condition in the future.

4) Diagnosis, Analysis is intended to see the possibility of problems - problems that occur either in management, operations, finance, or other problems in the company. 
5) Evaluation, Analysis is conducted to assess management's performance in managing the company. In Excerpt (Tri Putranto, 2018).

\subsection{Financial Performance}

According to Fahmi (2013) financial performance is an analysis carried out to see the extent to which a company has implemented it using the rules of financial implementation properly. Basically, financial performance reports are very useful for a company. Information on financial performance can be utilized in the following ways (Amalia, 2018):

1) Used as a basis for determining the company's strategy for the future.

2) Measuring the achievements of the company in a certain period that reflects the level of success of the implementation of its activities.

3) Assess the contribution of a part in achieving overall corporate goals.

4) The basis for determining investment policies so as to increase the efficiency and productivity of the company.

5) Seeing the company's overall performance

6) Providing instructions in making company decisions and activities in general and company divisions in particular.

\subsection{Economic Value Added}

Economic Value Added (EVA) was first popularized in the 1980s by George Bennet Stewart, one of the managing partners of a leading management consulting company, Stern Stewart \& Co, headquartered in New York. According to (Brigham F. Eugene, 2018) EVA is an estimate of actual business economic profit for a given year and is very much different from accounting net income where accounting profit is not reduced by the cost of temporary equity in the EVA calculation this fee will be incurred. From some of the opinions above, it can be concluded that the Economic Value Added provides a benchmark for how much the company provides added value to investors for a certain period.

The purpose of implementing EVA is expected to get a more realistic calculation of the company's economic value. According to (Susilowati, 2018) the provisions in seeing a business have occurred Economic Value Added or Value Added financial performance in the company, can be seen as follows:

1) If Economic Value Added >0, then the company's financial performance can be said to be good, because the company has succeeded in adding economic value for shareholders or investors. In this case the shareholders or investors get the same or more returns from those planted.

2) If Economic Value Added $=0$, it is economically "break even" because all profits are used to pay obligations to investors both creditors and shareholders.

3) If the Economic Value Added <0, then the company's financial performance is said to be bad, because the company cannot provide economic added value to the shareholders.

Economic Value Added (EVA) is calculated as follows:

NOPAT - (WACC X Invested Capital)

\subsection{Benefits of Economic Value Added}

According to Abdullah (2010) benefits obtained from the application of EVA models in a company include:

1) The application of EVA models is very useful for used as a measure of company performance where the focus of performance appraisal is value creation.

2) Assessment of financial performance using the EVA approach causes management's attention in accordance with the interests of shareholders. 
3) EVA encourages companies to pay more attention to the wisdom of their structure capital.

4) EVA can be used to identify projects or activities that provide a higher return than the cost of capital. (Dewi, 2017).

\subsection{Advantages and Disadvantages of Economic Value Added}

The advantage of EVA as a company performance appraiser is that it can be used as value creation. The advantages of Economic Value Added according to (Tunggal, 2001) in quotations (Lihawa, Maullanah. Montolalu, Jhonny. Tampi, 2018)are as follows:

1) EVA focuses on valuing added value by calculating expenses as a consequence of investment.

2) The EVA concept is a company tool in measuring expectations which is seen from an economic point of view by paying attention to the expectations of funders fairly where the degree of justice is expressed by a weighted measure of existing capital structure and guided by market value rather than book value.

3) Calculation of EVA can be used independently without requiring comparative data such as industry standards or other company data as the concept of valuation.

4) Easy application of EVA shows that the concept is a practical measure, easy to calculate and easy to use so that it is one of the considerations in accelerating business decision making.

In addition to various advantages, the EVA concept also has weaknesses. These weaknesses include (Rudianto nd):

1) Difficulty in determining the cost of capital that is really accurate, especially the cost of own capital. Especially in companies going public, they usually experience difficulties in calculating their shares.

2) Analysis of the Economic Value Added only measures quantitative factors. Whereas to measure company performance in an optimum manner the company must be measured based on quantitative and qualitative factors.

\subsection{Calculation of Economic Value Added}

The stages in determining Economic Value Added:

\section{1) Determine Weighted Average Cost of Capital}

Weighted Average Cost of Capital is the weighted cost of debt, Cost of Equity multiplied by composition of equity and debt in the company's capital structure that describes the minimum rate of return on investment to get the expected rate of return by investors. The calculations used are:

$$
\left(W_{d} \times K_{d}\right)+\left(W_{e} \times K_{e}\right)
$$

Description:

$\boldsymbol{K}_{\boldsymbol{d}} \quad$ : Cost of Debt

According (Husnan 2004) Cost of debt shows how much the company must bear because the company has used funds derived from the loan. The level of profit requested by the investor (Kd) is equal to the interest rate the company must pay if it has made a loan. To calculate costs after tax can be used by calculation:

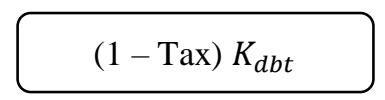

Description:

$K_{d b t} \quad$ : Interest Rate

Tax : Tax

$\boldsymbol{K}_{\boldsymbol{e}}$ : Cost of Equity

According to Stern Steward, cost of equity the level company must pay to the investor. One approach that can be used 
to calculate the cost of equity is the CAPM (Capital Asset Pricing Model) approach. This approach is the expected income from stock investment determined by risk-free investment income and market risk premium. The amount of risk in this approach is determined by the size of the systematic risk of $\beta$ shares (Made I Sudana, 2011). The amount of stock income is measured by calculation :

$$
K_{e}=R_{f}+\beta\left(R_{m}-R_{f}\right)
$$

\section{Description:}

$R_{f} \quad:$ Risk-free rate of return or deposit interest value at Bank Indonesia

$\beta \quad$ : Systematic risk of shares

$R_{m} \quad$ : Market return rate

Capital structure is a balance between capital from debt and equity. Capital structure in a company can be done by calculating the following:

$W_{d} \quad$ : Proporation of debt

$$
W_{d}=\frac{\text { Total Debt }}{\text { Total Debt }+ \text { Equity }} \times 100 \%
$$

$W_{e} \quad$ : Proporation of Equity

$$
W_{e}=\frac{\text { Total Equity }}{\text { Total Debt }+ \text { Equity }} \times 100 \%
$$

\section{2) Determine Net Operating After Tax}

Net Operating After Tax is the level of profit earned from invested capital. The tax used in the calculation of EVA is the sacrifice incurred by the company in creating the value (Amri, Prasetya, \& Ramadhan, 2017). Net Operating After Tax can be calculated by the formula:

$$
\operatorname{EBIT}(1-\text { Tax })
$$

Description:

EBIT : Earning Before Interest \& Tax

\section{3) Calculating Invested Capital}

Invested Capital is the amount of capital invested by the company by investors or creditors and how much capital is invested in the company ( Hefrizal 2018). Invested Capital can be calculated by the formula:

(Total Liabilitas + Total Ekuitas) - Liabilitas Short-Term 


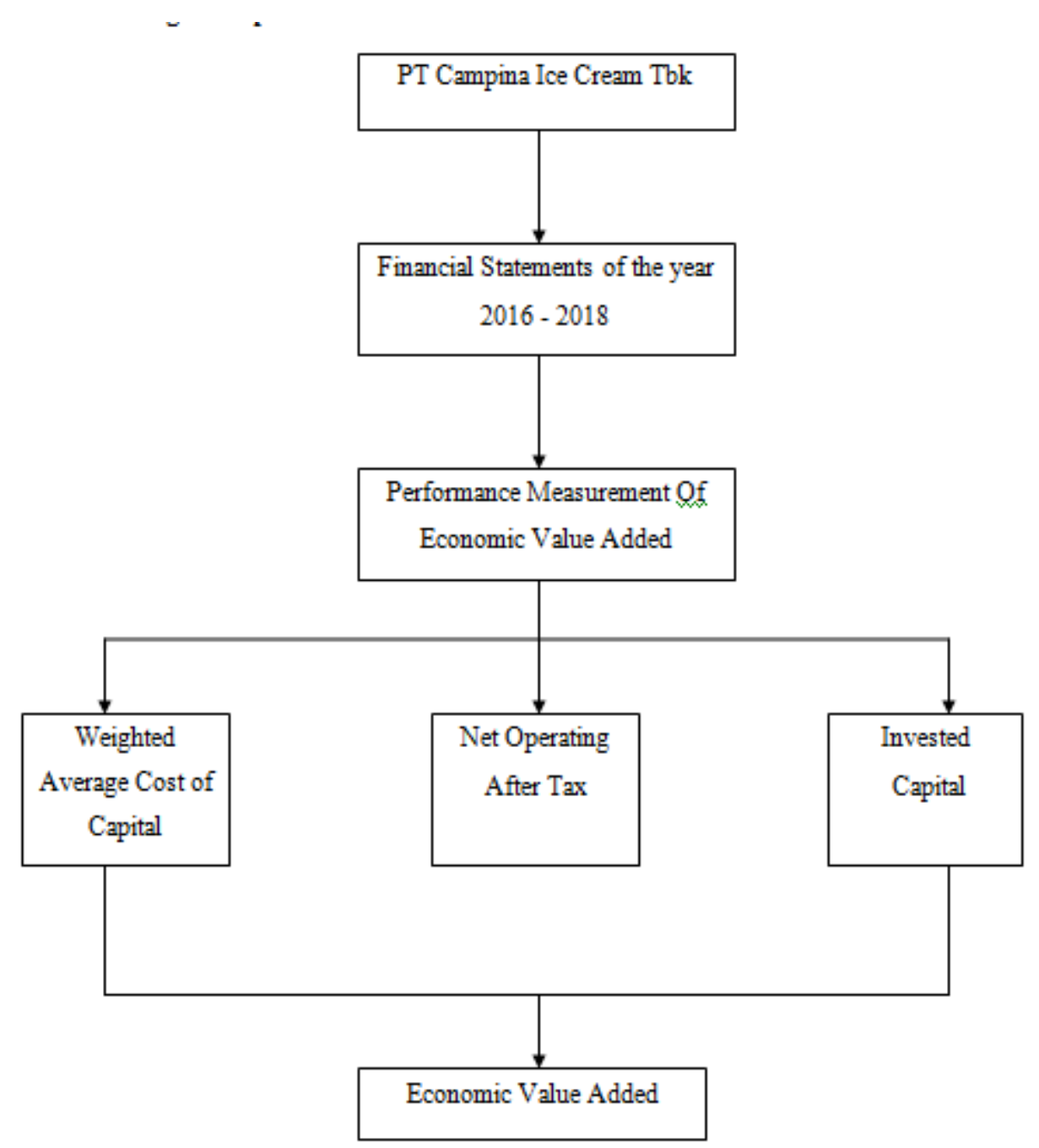

Fig. 1. Conceptual Framework

Source: (Data processed by 2019 authors)

\section{Methods}

This study uses a Qualitative Descriptive approach. In this study, the object of the research was PT.Campina Ice Cream IndustryTbk. The type of data used was quantitative data in the form of numbers from the financial statements of PT. Campina Ice Cream Industry Tbk. The data sources needed in this study are using secondary data obtained from the company's official website. This study uses the method Economic Value Added.

\section{Result and Discussions}

In this study, the assessment of financial performance using the Economic Value Added (EVA) method can be restated as follows:

\subsection{Analysis Weighted Average Cost of Capital}

Based on an analysis of the proportion of weighted average cost of capital items, namely $\mathrm{K}_{\mathrm{d}}$ (debt costs), $\mathrm{K}_{\mathrm{e}}$ (capital 
costs), $\mathrm{W}_{\mathrm{d}}$ (debt proportion), $\mathrm{W}_{\mathrm{e}}$ (proportion of capital), then the WACC value can be seen in table 2 .

Table 2. Calculation of Weighted Average Cost of Capital

\begin{tabular}{cccc}
\hline \multicolumn{4}{c}{ WEIGHTED AVERAGE COST of CAPITAL } \\
\hline INFORMATION & 2016 & 2017 & 2018 \\
\hline Proportion Debt & $46 \%$ & $31 \%$ & $12 \%$ \\
Proportion Ekuitas & $54 \%$ & $69 \%$ & $88 \%$ \\
Cost of Debt & $11 \%$ & $11 \%$ & $0 \%$ \\
Cost of Equity & $3 \%$ & $1 \%$ & $6 \%$ \\
WACC & $\mathbf{7 \%}$ & $\mathbf{4 \%}$ & $\mathbf{5 \%}$ \\
\hline
\end{tabular}

Source: (Data processed by 2019 authors)

Weighted Average Cost of Capital can describe the rate of return expected by investors. From the results of calculations in table 2, the Weighted Average Cost of Capital in the company experiences instability every year. In 2016 the rate of return received by investors reached 0.07 or $7 \%$, then the following year decreased. In 2017 the rate of return decreases by 0.04 or $4 \%$, this is due to a decrease in the cost of equity reaching 0.01 or $1 \%$ and in 2018 the rate of return has increased even though only $1 \%$ from the previous year which reached 0.05 or $5 \%$.

\subsection{Analysis Net Operating After Tax}

Based on the calculation of Net Operating After Tax at PT.Campina Ice Cream Industry Tbk can be restated in table 3.

Table 3 Calculation of Net Operating After Tax

\begin{tabular}{cccc}
\hline \multicolumn{4}{c}{ NET OPERATING AFTER TAX } \\
\hline INFORMATION & 2016 & 2017 & 2018 \\
\hline Profit Before Income Tax & 75.603 .806 .052 & 58.384 .115 .529 & 84.038 .783 .563 \\
$(1-25 \%)$ & 0,75 & 0,75 & 0,75 \\
\hline TOTAL & $\mathbf{5 6 . 7 0 2 . 8 5 4 . 5 3 9}$ & $\mathbf{4 3 . 7 8 8 . 0 8 6 . 6 4 7}$ & $\mathbf{6 3 . 0 2 9 . 0 8 7 . 6 7 2}$ \\
\hline
\end{tabular}

Source : (Processed by the author in 2019)

From table 3, the results of the calculation of Net Operating After Tax, it can be seen that the company in the last 3 years has experienced instability. In 2016 Net Operating After Tax worth Rp. 56,702,854,539. Then in 2017 Net Operating After Tax company experienced a decrease of Rp. 43.788.086.647, this decrease was due to a decrease in income before income tax. In 2018 Net the company's Operating After Tax increased by Rp. 63.029.087.672. To increase Net Operating After Tax, companies should increase sales more, look for investors who can increase the company's capital and re-evaluate the operational budget and management of the company's strategy.

\subsection{Analysis Invested Capital}

Invested CapitalAnalysis on PT.Campina Ice Cream Industry Tbk can be seen in Table 4. On the statement of financial position Balance Sheet as of December 2016, total liabilities and equity worth Rp. . 1.031.041.060.010 reduced by liabilities short-term worth Rp. 168.764.411.246 so that Invested Capital is worth Rp. 862.276.648.764. In the same way for the following year can be known Invested Capital annually in table 4.5. Invested Capital or invested capital, based on table 4.5 which has the highest capital in 2017 worth Rp. 1.156.54.495.216 while in 2018 Invested Capital has a value of Rp. 942.952.838.655. 
Table 4 Calculation of Invested Capital

\begin{tabular}{lrrr}
\hline \multicolumn{5}{c}{ INVESTED CAPITAL } \\
\hline \multicolumn{1}{c}{ INFORMATION } & \multicolumn{1}{c}{2016} & \multicolumn{1}{c}{2017} & \multicolumn{1}{c}{2018} \\
\hline Total Liabilitas + Total Equity & 1.031 .041 .060 .010 & 1.211 .184 .522 .659 & 1.004 .275 .813 .783 \\
Liabilitas Short-Term & 168.764 .411 .246 & 54.639 .027 .443 & 61.322 .975 .128 \\
\hline TOTAL & $\mathbf{8 6 2 . 2 7 6 . 6 4 8 . 7 6 4}$ & $\mathbf{1 . 1 5 6 . 5 4 5 . 4 9 5 . 2 1 6}$ & $\mathbf{9 4 2 . 9 5 2 . 8 3 8 . 6 5 5}$ \\
\hline
\end{tabular}

Source: (Processed by authors in 2019)

\subsection{Analysis Economic Value Added}

The following analysis of Economic Value Added PT.Campina Ice Cream Industry Tbk in 2016-2018 can be seen in table 5 .

Table 5. Calculation of Economic Value Added

\begin{tabular}{cccc}
\hline \multicolumn{5}{c}{ ECONOMIC VALUE ADDED } \\
\hline INFORMATION & 2016 & 2017 & 2018 \\
\hline NOPAT & 56.702 .854 .539 & 43.788 .086 .647 & 63.029 .087 .672 \\
WACC & $7 \%$ & $4 \%$ & $5 \%$ \\
Invested Capital & 862.276 .648 .767 & 1.156 .545 .495 .216 & 942.952 .838 .655 \\
\hline TOTAL & $\mathbf{- 3 . 6 5 6 . 5 1 0 . 8 7 5}$ & $\mathbf{- 2 . 4 7 3 . 7 3 3 . 1 6 2}$ & $\mathbf{1 5 . 8 8 1 . 4 4 5 . 7 3 9}$ \\
\hline
\end{tabular}

Source : (Processed by authors in 2019)

Economic Value Added is the ability of company management to produce value added to shareholders in a certain period. Based on the results of calculations in table 5 , it can be seen how much added value is produced by PT.Campina Ice Cream Industry Tbk.

In 2016 the value of Economic Value Added produced by the company was Rp. (3.656.510.875) and in 2017 PT. Campina Ice Cream Industry Tbk returns to generate added value or Economic Value Added negative which is worth Rp. (2.473.733.162) so that the company has not been able to generate added value to the shareholders.

In 2018 PT.Campina Industry Tbk be a success in generating Economic Value Added positive value of Rp. 15.881.445,739 which means that PT.Campina Ice Cream Industry is able to generate value added for the company because net income after tax or (NOPAT) has increased in previous years which is able to cover liabilities to investors.

Company performance through the EVA approach is very important for investors or shareholders. With the method EconomicValue Added, company managers consciously create value added because this is what shareholders will appreciate. The greater value added they create, the higher potential profits for investors. If the company can always meet the expectations of shareholders, the value of the company will continue to increase.

\section{Conclusions}

Based on the results of research and discussion conducted by research at PT. Campina Ice Cream Industry Tbk, it can be concluded that assessment of financial performance using method Economic Value Added from 2016 to 2018 is instability. Where, in 2016 the value of the Economic Value Added generated was Rp. (3.656.510.875) and in 2017 valued at Rp. (2.473.733.162) shows the value of Economic Value Added $<0$ or negative which can be said that financial performance is not good because company's cannot provide economic value added to investors. In 2018 the company succeeded in achieving value of Economic Value Added > 0 or positive worth Rp. 15.881.445.739 then, it can be concluded that the company's financial performance is good and has resulted in the value aded expected by the 
shareholders or investors. This shows that Economic Value Added can be used as a measure of creating added value from an investment in a company.

\section{References}

Amalia, D. (2018). Laporan Keuangan Tepat untuk Penilaian Kinerja Keuangan Perusahaan. Retrieved January 8, 2018, from https://www.jurnal.id/ID/BLOG/2018-Laporan-Keuangan-tepat-untuk-Penilaian-Kinerja-KeuanganPerusahaan/

Amri, N., Prasetya, E. B., \& Ramadhan, Y. H. (2017). Penerapan Metode Economic Value Added (EVA) pada Aplikasi Penjualan Berbasis Yii Framework (Studi Kasus: Salam Digital Image). Justit Umj, 7.

Brigham F. Eugene, H. F. J. (2018). Dasar - Dasar Manajemen Keuangan Edisi 14 - Buku 1.

Dewi, M. (2017). Penilaian Kinerja Keuangan Perusahaan dengan Menggunakan Metode EVA (Economic Value Added ) ( Studi Kasus pada PT . Krakatau Steel Tbk Periode 2012-2016 ). 6(1), 648-659.

I.N.Adiguna., S.Murni., J. T. (2015). Analisis Kinerja Keuangan dengan menggunakan Metode Economic Value Added (EVA) pada Perusahaan Plastik dan Kemasan yang terdaftar di Bursa Efek Indonesia Periode Tahun 2011 - 2015. 5(2303-1174), 433-442.

Lihawa, Maullanah. Montolalu, Jhonny. Tampi, D. L. (2018). Analisis Penilian Kinerja Keuangan Perusahaan dengan Menggunakan Metode Economic Value Added pada PT. Bank Rakyat Indonesia(Persero) Tbk. 6(3), $44-51$.

Made I Sudana. (2011). Manajemen Keuangan Perusahaan Teori\&Praktik (I. N. Sallama, Ed.). Penerbit Erlangga.

Rudianto. (n.d.). Akuntansi Manajemen Informasi untuk Pengambilan Keputusan Manajemen. Retrieved from https://books.google.co.id/books?id=_4nn7njUp3wC\&pg=PA353\&lpg=PA353\&dq=kelemahan+eva+investope dia\&source=bl\&ots=cITIOW65_f\&sig=ACfU3U24rFAbJUNOhMfrYgvGRtsBLSgwfg\&hl=en\&sa=X\&ved=2a hUKEwi0j4jO4_bhAhWD4nMBHfL4CdoQ6AEwEHoECAkQAQ\#v=onepage\&q\&f=false

Tri Putranto, A. (2018). Analisis Laporan Keuangan Untuk Menilai Kinerja Keuangan Pt Mayora Indah Tbk Tangerang Jurnal Sekuritas. Jurnal Sekuritas, 11(33), 1-26. 